\title{
Indonesian Female Police Officer's Deployment as International Police Officers in United Nations - African Union Mission in Darfur (UNAMID) (2016-2018)
}

\author{
Witri Elvianti \\ International Relations Study Program, President University, \\ Cikarang Indonesia \\ witrielvianti@president.ac.id \\ Meilisa Rusli \\ International Relations Study Program (Alumni), President University, \\ Cikarang Indonesia \\ Meimeilisa97@gmail.com
}

\begin{abstract}
The main purpose is to analyze the role of Indonesian female police deployed as Individual Police Officers in the United Nations peacekeeping operation in Darfur from 2016 to 2018. This research was designed as a qualitative case study that triangulated data from previously published researches, institutional documents, and semi-structured qualitative interviews. Previous scholarly publications were used to observe gender deficit - which is the lack of female personnel in UN peacekeeping missions. Institutional documents, particularly ex-Indonesian female police reports, were analyzed to contribute to data enrichment in this research. Lastly, the authors conducted semi-structured qualitative interviews with some ex-female police who have completed their deployment in UNAMID (2016-2018). Concerning the gender equality and counterinsurgency concepts, this research figured out that Indonesian female police could demonstrate their strategic role to provide skill-building activities, trust-building with refugees, and human rights advocacy. The numbers of Indonesian female police in this mission remained higher than other Southeast Asian contributing countries, but the Indonesian female police were also functional in line with the UN gendering peace and security agenda.
\end{abstract}


Keywords: gender, peace, international peacekeeping, international police

\begin{abstract}
Abstrak
Tujuan utama dari tulisan ini adalah untuk menganalisis peran polisi wanita Indonesia yang ditempatkan sebagai Individual Police Officers dalam operasi perdamaian Perserikatan Bangsa-Bangsa di Darfur dari tahun 2016 hingga 2018. Penelitian ini dirancang sebagai studi kasus kualitatif yang melakukan triangulasi data dari penelitian yang dipublikasikan sebelumnya, kelembagaan. dokumen, dan wawancara kualitatif semi-terstruktur. Publikasi ilmiah sebelumnya digunakan untuk mengamati masalah defisit gender saat ini - yaitu kurangnya personel wanita dalam misi penjaga perdamaian PBB. Dokumen kelembagaan khususnya laporan eks Polri dianalisis untuk membantu pengayaan data dalam penelitian ini. Terakhir, para analis melakukan wawancara kualitatif semi terstruktur dengan beberapa mantan polisi wanita yang telah menyelesaikan penempatannya di UNAMID (2016-2018). Dengan mengacu pada kesetaraan gender dan konsep kontra-pemberontakan, penelitian ini menemukan bahwa polisi wanita Indonesia mampu menunjukkan peran strategis mereka dalam memberikan kegiatan peningkatan keterampilan, membangun kepercayaan dengan pengungsi, dan advokasi hak asasi manusia. Meskipun jumlah polisi wanita Indonesia dalam misi ini masih terbilang kurang signifikan, tetapi polisi wanita Indonesia telah berperan sesuai dengan agenda perdamaian dan keamanan berbasis kesetaraan gender PBB.
\end{abstract}

Keywords: gender, perdamaian, penjagaan perdamaian internasional, polisi internasional

\section{INTRODUCTION}

Maintaining public safety and security and ensuring law enforcement is part of police's minimum essential tasks when a normal situation is met. However, the task performed by the police in conflict areas remains more complicated. It is primarily addressed to guarantee security and prevent the perpetuation of conflict and improve the social foundation in society to reach reconciliation and reconstruction. In the realm of a post-conflict society, social cohesiveness is likely the key 
to attaining productivity after suffering from the deficit of trust towards government accountability. Therefore, the police hold, prima facie, a legitimate task to ensure civilians' security in the conflict areas (Loh, 2010).

Given the strategic position the police employ, United Nations peacekeeping missions prioritize this sector as one of the main components in UN peacekeeping operations worldwide. United Nations Police is assigned in areas where UN missions are carried out, in which the police are given tasks to assist the government in maintaining public security and increasing local police capacity. The United Nations Police is divided into three sections, namely Professional Post (P-Post) or Specialized Police Team, Formed Police Unit (FPU), and Individual Police Officer (IPO). Each of the units equally shares the same goal to complete the UN peacekeeping missions. In such deployments, personnel from various backgrounds and diverse professional ranks and experiences are being challenged to face a wideranging mandated responsibility. The Individual Police Officer, for instance, which also becomes the main focus of this research, covers a complete range of policing tasks, such as developing community police camps for refugees or internally displaced persons, mentoring and training national police officers, providing specialization in different types of investigations and helping law enforcement officers to deal with transnational crimes happened in some countries (United Nations, 2017).

Speaking of which United Nations peacekeeping operations that seek to fulfill some golden goals, among other things, maintaining international peace and security based on respect for the principle of equal human rights and selfdetermination of peoples; helping the member states to earn friendly relations through multilateral cooperation coping with global social, cultural, economic and humanities challenges. Such normative assertions may not always be retained. In the context of equal human rights in international security, the UN police seem to demonstrate its commitment to adopting the gender equality policy as an operational standard to be held throughout its missions as to fulfilling a variety of needs of women, men, girls, and boys emerged in the field. It is supposedly able to "... increase the number of women in the composition of military and police 
contingents in UN peacekeeping..." to internally gendering the institutions and aiming for "...equal representations of women within the UN operation..." (Dharmapuri, 2013). Accelerating number of women police in UN missions enables the global efforts to the pursuit of women empowerment in enhancing law enforcement, public leadership, crisis management and investigations, capacity-building for local police, and communityoriented policy realization and raising awareness of gender equality for the local community (United Nations Police, 2016).

Besides, since early 2000, initiatives to incorporate women into the decision-making process at any level in peace processes have been intensified in the UN Security Council report progress. From late October 2000, through its $4213^{\text {th }}$ meeting, the UN eventually disqualified masculine superiority, adding that Beijing's Commitment to gender mainstreaming was encapsulated in UN Resolution 1325. This resolution became a stepping stone for the member states to be keen on gender mainstreaming in the security sector domestically and internationally. To continue the commitment, the UNSC has adopted Resolution 1820 in 2008,
Resolution 1888 and 1889 in 2009, Resolution 1960 in 2010, Resolution 2106 and 2122 in 2013. These resolutions intended to strengthen the commitment of member states to adopt the women, peace, and security (WPS) agenda in international and national security.

Such UNSC's agenda galvanizes member states to strengthen their military and police capacity by equipping their personnel with principles of gender equality. The international community witnesses the presence of UN peacekeepers in times of militarization and war is presumably exclusive and genderneutral. However, it turns out ironic that the peacekeepers who are taught to be non-gender biased are involved in a series of complaints. The blue helmet units are deployed in conflict zones to continue demilitarization and peaceful reconciliation by mostly resembling malecentric authority. This condition subsequently generates a classic image of what 'militarization' can be a symbolic and powerful cultural tool imposed by the government to further its aggressive goals. This masculine concept of peacekeeping operation led women into the least proportion of military and civilian police personnel, where 16 percent of civilian police composed less than 
five percent of female police in UN peacekeeping operations. Although statistically improvement has been viewed from the mid-1990s, women personnel, however, have been authorized for “...non-professional civilian positions” (Mazurana, 2003)

Hence, the gender equality policy in UN peacekeeping operations should gain more supports from the international community. The purpose is to encourage more female personnel to get involved in "...the building and preserving peace..." as the presence of female peacekeeping personnel remains as "...one of the preconditions for...” emergence of “...sustainable peace and stability in the conflict zones" (Odanovic, 2010). The gendering security agenda also continuously sounds in the international police deployment in a series of UN peacekeeping operations to empower female police personnel at the frontline of peacekeeping missions by accelerating their leadership capacities in crisis management.

One of the UN Peacekeeping missions that attract scholarly debates upon the arrival of female police personnel in this operation is the UN peacekeeping operations in collaboration with African Union within the so-called United Nations -
African Union Hybrid Operation in Darfur (UNAMID, 2017). This case remains worth scholar discussion and rigorous investigation to examine the relevance of female personnel towards attaining effective post-conflict civilian reconciliation. The civil war that emerged in Darfur involved two confronting parties between the Sudanese government and armed rebel groups - led by the Sudan Liberation Army (SLA) and the separate Justice and Equality Movement (JEM) that has existed since 2003. These two rebels started attacking North Khartoum due to its indifference with the Sudanese government by arguing that the people of Darfur have long been ethnically and politically marginalized. In response, the government formed the so-called Janjaweed, the Arab's militias. This decision worsened the situation in Darfur and made the conflict one of the worst humanitarian conflicts in the region.

Consequently, it has resulted in 300,000 deaths, 2.5 million displaced people, and increased crime rates (UNAMID, 2017). Violence against vulnerable women and children cannot be separated from conflicts or wars, in which civil wars in Darfur are not excluded. The violation ranges from rape, sexual abuse, 
sexual exploitation, and murder. Women and children in Darfur are targeted because Janjaweed accused them of supporting the armed rebel groups (Human Rights Watch, 2015). Violence toward women and children is the most destructive strategy in war and conflicts (United Nations Police, 2016).

In this vein, the conflict demanded intervention from external parties to end the casualties or minimize power abuse performed by the conflicting parties. Although Darfur Peace Agreements were attained, the conflict was rather prolonged. The government and the armed rebel group declared war to pursue military gains, targeting civilians (Netabay, 2009). The innocent civilians have suffered a wide range of mistreatments, such as harassment, sexual abuse, rape, beatings, and murderer (U.S.Department of State, 2017). Hence, the United Nations protected them by sending approximately 31.042 personnel to Darfur (19.555 soldiers, 3.772 police advisers, and 5.105 civilians) (United Nations, 2007). The mission named UNAMID came into force through the UN Security Council Resolution 1769 that was adopted on July 31, 2007 (United Nations, 2007).
The Indonesian government has participated in the United Nations African Union Hybrid Operation in Darfur (UNAMID). Indonesia is one country that has assigned its national police to participate in the UN Peacekeeping mission. Indonesia's participation in the mission is in line with one of the country's national goals, which is to participate in carrying out world order based on independence, peace, and social justice as mentioned in the fourth paragraph of the Preamble of the 1945 Constitution (The Constitution of the Republic of Indonesia of 1945, 1945). Indonesian Law No. 2 of 2002 Article 41 paragraph 3 also emphasizes the importance of the national police's participation in peacekeeping missions, which stated that the Indonesian National Police actively assisted the task of maintaining world peace (UndangUndang Republik Indonesia Nomor 2 Tahun 2002 Tentang Kepolisian Negara Republik Indonesia, 2002).

In its contribution to the UN peacekeeping operations in Darfur, Indonesia has shown consistent, albeit quantitatively lower, performance. Albeit Indonesian peacekeeping personnel was absent in the first commencement of UNAMID in 2007, the government of Indonesia has continuously been 
active in supporting the gendering peace process by sending higher numbers of police personnel.

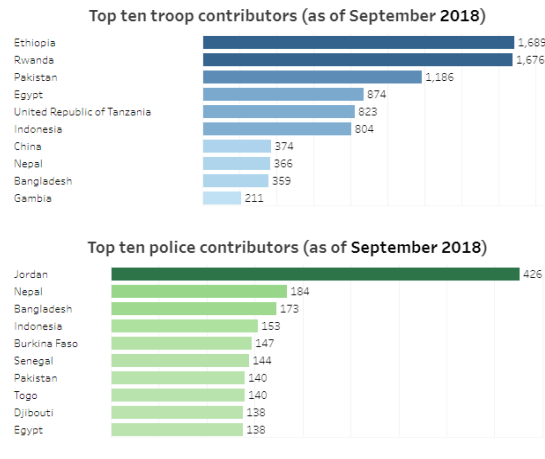

Figure 1. List of top ten troops and police-contributing countries in

September 2018

(Source: https://peacekeeping. un.org/en/troop-and-policecontributors)

Based on Figure 1, the quantity of Indonesian police remains lower than in Jordan, Nepal, and Bangladesh. Also, the Indonesian government seems to prioritize the deployment of military personnel over the police since the number of police was still below the military troops, with 168 police personnel and 804 military personnel in 2018 . However, before the deployment in any UN Peacekeeping operations, military personnel would have been granted multiple protections in the wider context, making monitoring over disciplining personnel affordable. The military contributors would sign the MOU with the United Nations, ensuring that each military unit could be protected from national military codes of justice. The UN code of conduct would also guide its minimum essential task.

On the contrary, the police unit in UN peacekeeping operations does not earn such protective circumstances since the protection for police is solely the responsibility of the contributing country. Consequently, the numbers of police contributions in UN peacekeeping operations remain slower than the numbers of military personnel. Besides, due to alarming power abuse and weak discipline demonstrated by UN police personnel in UN peacekeeping operations leads the credibility of UN police is underrated (Durch \& Ker, 2013).

The government of Indonesia should have been able to increase the numbers of its national police deployed in UN peacekeeping missions. It has been suggested and mandated by several legal decisions that supervise the participation of the Indonesian National Police in the peacekeeping mission in Darfur. The first legal base is Regulation of the Chief of the Indonesian National Police Number 01 of 
2013 and Regulation of the Chief of the Indonesian National Police Number 13 of 2014 concerning the assignment of Indonesian police officers outside the organizational structure of the national police (Wibisono, 2018). The second legal basis is Order Letter from the Chief of the Indonesian National Police Number: Spring/301/II/2017 dated February 8, 2017, which concerns orders to carry out assignments as Individual Police Advisor to the United Nations mission area NAMID-Darfur (Wibisono, 2018). Last but not least, another legal basis is Facsimile (Fax) from Head of International Relations Division of the Indonesian National Police Number: Divhubinter/Fax/2271/ XII/2014 dated December 10, 2014, concerning Making Reports on IPO Assignment in the United Nations Mission Area (Wibisono, 2018).

Given such information, this research asked how the Indonesian female police could contribute to the peacekeeping operations underneath the UNAMID authority in Darfur. Although quantitatively numbers of Indonesian national police remain lower than other developing countries, it is worth asking whether or not Indonesian female police could perform quality international policing when on the international mission; whether or not Indonesian female police deployed in this mission was conscious of how significant their contribution toward peace establishment for local people in Darfur and career development for their future career. This research specifically portrayed the gender dimension of Indonesian police personnel in UNAMID to justify that the Indonesian government under the Indonesian national police unit is likely progressive to welcoming the gender perspective in its commitment to be proactive in the international peace and security arena. Specifically, this research focused on Individual Police Officers (IPO) that consisted of police or other law enforcement staff/personnel of different ranks and experience assigned by UN member states for deployment (United Nations, 2017). IPO covers a complete range of policing tasks, such as developing community police camps for refugees or internally displaced persons, mentoring and training national police officers, providing specialization in different types of investigations, and helping law enforcement officers deal with transnational crimes in some countries (United Nations, 2017). The personnel selected to be a member of IPO must be ready to 
be placed anywhere by the UN (Wibisono, 2018).

Previous researches attempted to build a positive correlation between the UN police and UN peacekeeping operations. The scholarly analysis provided by Bayley and Perito in 2010 investigated the dilemma of establishing legitimate and effective indigenous police forces amid insurgent violence. They focused on police-building in stability operations, intending to create a legitimate and effective government that can provide important services, including the rule of law. As a result of the experience in Iraq and Afghanistan, the U.S. military has recently developed a new counterinsurgency doctrine (COIN) to address the kind of violence encountered in stabilization missions, with the ultimate goal of establishing an effective, sustainable local government (Bayley \& Perito, 2010). In this study, the greater importance of local police presence was also found since there was a huge gap between the local community of Darfur and the local police. The civilians remained lacking in trust toward the police credibility. It was also unveiled that the victims of sexual abuse were hindered from reporting the violence simply because they distrusted the institution.

A study by Fitri Bintang Timur published in 2016 focused on studying the urgency of female peacekeepers on a comparative basis with selecting three Asian countries, such as Indonesia, the Philippines, and India. Comparing the performance of female military personnel deployed in UN peacekeeping missions, this research found that although Indonesia's contribution in terms of security personnel deployed in UN peacekeeping missions remained the highest contributor in Southeast Asia, the number of female personnel deployed remained the lowest. Concerning the statistical data from UN PKO from 2009 to 2014, this research figured out that one to two out of a hundred peacekeepers deployed were female. The study concluded that female peacekeepers' recruitment mechanisms remained half-hearted, which caused the low performance in numbers and qualities (Timur, 2016).

Therefore, the analyst found the urgency to evaluate the contribution of Indonesian female police to UN peacekeeping missions, with specific attention being paid to the case of Indonesia's contribution to UNAMID. By doing so, it is expected 
to unveil the direction of Indonesian female police performance by exploring whether or not their contribution fulfilled the gendering peace and security agenda and the method of counterinsurgency that emphasizes the urgency of the human security dimension in UN peacekeeping operations.

\section{THEORETICAL FRAMEWORK AND RESEARCH METHOD}

To achieve the goal, the analyst employed some concepts and theories as mentioned below:

\section{a. Gender Equality}

Gender not only corresponds to biological identity but is primarily a product of socialization, or cultural, political, and social structure of the masculinity and feminist as the identity of a social character (Arsenijevic \& Flessenkamper, 2013). Gender can also be seen to structure power relations and define power relations in society to determine what is expected, allowed, and valued in a given context for women or men (Guehenno, 2006). However, it is well-known that violent conflict affects women and girls in gender inequalities and discrimination (United Nations, 2015).
Gender equality itself refers to women's and men's equal rights, responsibilities, and opportunities and implies that the interests, needs, and priorities of both men and women are taken into consideration, recognizing the diversity of different groups of men and women (Guéhenno, 2006). On the contrary, gender inequality means that women's and men's rights, responsibilities, opportunities, and priorities are not equal.

The gender equality concept provides a relevant background of why female police are part of UN strategic units in this research. United Nations has strived to emphasize and incorporate gender equality into its policies and programs. One of the policies applied by the UN is the United Nations Security Management System (UNSMS). The UNSMS policy on Gender Considerations in Security Management was developed to raise awareness and guide security decision-makers in assessing and addressing security-related threats, risks, and vulnerabilities of all United Nations personnel, especially those most vulnerable (United Nations, 2016). Formed Police Unit and Individual Police Officer can be said as parts of UN program which is United Nations Police concerned 
with gender equality in the security sector. This program is open for all genders to maintain public security in some areas known as war-zone areas. To be part of the Formed Police Unit and Individual Police Officer, every personnel must pass some criteria and tests. After that, the person can become part of the United Nations Police that are ready to be placed anywhere regarding the areas that need UN Police and have approval from the local government.

\section{a. Counter Insurgency Doctrine \\ COIN doctrine emphasizes} the need to protect civilians, eliminate insurgent leaders and infrastructure, and help establish a legitimate and accountable host nation government capable of delivering essential human services (Eikenberry, 2013). According to a book titled "The Police in War: Fighting Insurgency, Terrorism, and Violent Crime" by David H. Bayley and Robert M. Perito, they shared their thoughts about the role of the police and military commander who are responsible for making decisions immediately to secure peace and human security. In this book, Bayley and Perito stated that "Military victory in war is easier to achieve than peace, although it is equally important that's why the presence of actors in the field of military security, police security and human security is crucial" (Bayley \& Perito, 2010).

This research used qualitative descriptive, which is largely descriptive and analytical, by interpreting the official government's document as the primary data. The analyst triangulated data to check for data validity by combining information from various secondary and primary sources to validate the data gathered in this research. The data triangulation technique demonstrated in this research covered reviewing previous scholarly reports, text analysis of official documents, and individual interviews through semi-structured qualitative interviews with the female police who accomplished their one-year (2017-2018) mission in Darfur.

At the first stage, the researcher identified the problems that emerged to justify why it remains necessary to question the relevance of gender equality in the UN peacekeeping missions. In this process, data was required. The variables of sexual abuse victimized women and children, lacking the discipline of UN police and military personnel, and masculine militaristic approach in conflict areas, especially in Darfur. In the next stage, to ensure data 
richness, the researcher subsequently analyzed the text of official documents, including (1) Reports from the personnel who have been deployed to the mission area; (2) and United Nations Security Council Resolution. The last stage of this data gathering process was retrieved from theoretical propositions that have been explained in previous paragraphs. To check for its validity, through interviewing exfemale peacekeepers (police unit), the authors found relevant data about some variables, which were the realization of gender equality in UNAMID, the outcome of a female police officer deployment, and the experience of a female police officer facing the challenges resulting from such a crisis zone. This data articulation is relevant to the grand theme brought by this research which was to build a comprehensive conversation on the role and contribution of Indonesian female police as Individual police officers under the United Nations African Union Hybrid Operation in Darfur, since 2017 - 2018, especially in the protection of women and children from the humanitarian crisis because of Darfur Conflict.

However, when contacting the informants to gain primary data, the researcher should admit the lack of time to conduct individual interviews. The time constraint vastly pushed the researcher to not handle the interview directly but through email correspondence. This circumstance, however, reduced the probability of enriching primary data from the informants. Therefore, the analysis generation process most depended on the written interaction through texts and replies via email

\section{RESULT AND EXPLANATION}

According to NCB-Interpol Indonesia, Indonesian police personnel deployed in UN mission can be categorized into three forms, Professional Post (P. Post), Individual Police Officer (IPO), and Formed Police Unit (FPU) that have the same goal which is to complete UN's Peacekeeping missions (NCBInterpol Indonesia, 2017). Individual police officers (IPOs) are police officers or other law enforcement personnel of various ranks and experience assigned to serve with the United Nations by governments of the Member States which have the main task of the Physical Protection of Civilian and the Creation of Protective Environment (United Nations, 2017). Especially for female police, other main duties are to protect women and children, function as community 
policing, building interaction with local women and children (United Nations Peacekeeping, 2018). United Nations ensures gendersensitive policing throughout the work of United Nations Police as an operational necessity to overcome the differentiated security needs of women, men, girls, and boys (United Nations Police, 2016). The participation of women police is important in United Nations Police activities, such as the promotion of the rule of law, intelligence, planning, leadership, investigations, and public order management, capacity-building of host-State police, community-oriented policing, gender awareness-raising, and engaging communities (United Nations Police, 2016).

In addition, women police act as role models for gender equality and inspire women to encourage their rights and pursue careers in law enforcement also to provide a greater sense of security to women and children and improve access and support from law enforcement agencies to local women (United Nations Police, 2016). Women Police also help the United Nations address and respond to sexual exploitation and abuse (United Nations Police, 2016). Such participation of women police was emphasized through
Security Council Resolution on Women, Peace and Security 1325 (2000), 1769 (2007), 1820 (2008), 1888 (2009), 1889 (2009), 1960 (2010), 2106 (2013), 2122 (2013), and 2242 (2015) which talked about the important roles of women in the prevention and resolution of conflict and peace-building and for their equal participation and full involvement at decision-making levels in conflict resolution and maintenance and promotion of international peace and security (United Nations Police, 2016).

Given such global normative procedures, it becomes pertinent to ask how the Indonesian female police perceive their presence in Darfur as delegated by Indonesian National Police to adopt gender mainstreaming policy. According to the data gained from one of the interviewees, the Indonesian government's policy in international security has gradually reflected the gender mainstreaming agenda. In the case of Indonesian peacekeepers deployed in the UN peacekeeping mission in Darfur, from 2017 to 2018, 9 out of 15 Indonesian police personnel deployed in UNAMID were female (Astuti, 2017).

Furthermore, those nine female police personnel demonstrated their position as Individual Police Officer 
in various types of contributions. Some were appointed to manage strategic roles as patrol officers, administrative officers, and team leaders in sub-unit at UNAMID main headquarters. Yunik Dwi Astudi herself managed every Individual Police Officers who departed from many other countries who eventually accomplished their deployment. Some soft skills were determinant to the successful accomplishment. Facing the pressure from the culturally different local community and handling complaints from other female personnel due to financial miscalculation of their Monthly Substantial Allowance (MSA) were other responsibilities facing AKBP Yunik Dwi Astuti during her deployment in UNAMID.

The other Indonesian women police was Kompol Rusdiani, SIK, MSi. Getting assigned as Internal Investigation Officer, Kompol Rusdiani was responsible for investigating various cases in that area, such as harassment, stealing, etc. (Syam et al., 2017). The Indonesian female police should investigate the roots of the problem and provide traumatic healing for the victims of sexual harassment. Another Indonesian female police who strategically performed a crucial role in UNAMID was Iptu
Wastini, assigned to a training officer who had to train all Individual Police Officers from other countries such as Tanzania and Malawi, Rwanda, and South Africa. Before this position, Iptu Warsini became a certifiedNSAAT Tester and International Trainer from United Nations (AKBP Yunik Dwi Astuti, SIK, MSi, 2017). Besides, Brigadier Fraya Sadewi; AKBP Dr. Imanta Tarigan; Bripka Aprina Pohan; Bripka Anastasia Helena Rompas; Bripka Ni Nyoman Trisna Oktaviani; and Bripka Lucy Veronika were other Indonesian female police assigned as IPO in UNAMID with their unique roles. Brigadier Fraya Sadewi was assigned as Protocol Officer whose duty was to communicate with the representatives or the president of the Sudanese government, the UNAMID Officials, and the delegates who came to visit the mission area. AKBP Dr. Imanta Tarigan was assigned as Welfare Officer in the South Sector and responsible for handling stress management. Bripka Aprina Pohan was assigned as a Planning Officer in the South Sector, which must plan the strength of personnel in this sector and the on-Site team to support the territorial patrol. Bripka Anastasia Helena Rompas 
and Bripka Ni Nyoman Trisna Oktaviani were appointed as Admin Officer. However, Bripka Anastasia Helena was assigned in the South Sector, and $\mathrm{Ni}$ Nyoman Trisna Oktaviani was differently assigned in the West Sector and responsible for managing given information about the administrative movement to all personnel in their Sector, Site Team, and Main Headquarter. Last but not least, Bripka Lucy Veronika, who was assigned as Joint Operations Center (JOC) Officer in Central Sector which had the duty to prepare, collate and disseminate JOC products promptly, including regularly scheduled daily and weekly mission situation reports and adhoc reports such as special incident reports (Syam et al., 2017).

With the specific role as a patrol officer, the personnel had opportunities to interact with local people in refugee camps to maintain public security. Direct engagement with local villagers could help the person build trust with the people and track the safety of the people in Darfur. Patrol officers also monitored the crime potentials in that area, including the cases of sexual gender-based violence, by collecting and analyzing information about the dynamism of the crimes. Next, the personnel identified the crime-prone areas and warned local people to stay away from the dangerous area (AKBP Muhammad Nur Syam, S.I.K.; AKBP dr. Sn Imanta Taringan, SpPK; Bripka Lusy Veronika, S.Pd., 2017). Adding to that, this female IPO also performed other roles: (1) provide several skillsbuilding activities such as teaching about self-security, personal health and the environment, ways of breastfeeding, and children's education; (2) enhance the local policewomen capacity to take a leading responsibility in providing support to local communities; and (3) ensure the safety of refugees from criminal acts that will happen around mission area (NCB-Interpol Indonesia, 2017); (4) provide counseling and capacity building at refugee camps; (5) and community policing, human rights education and health.

Based on the UNAMID mandates, which are to (1) protect civilians, without prejudice to the responsibility of the Government of Sudan; (2) facilitate the delivery of humanitarian assistance and ensure the safety of humanitarian personnel; (3) mediate between the Government of Sudan and nonsignatory armed movements based on the Doha Document for Peace in Darfur; and (4) support the 
mediation of community conflict, including through measures to address its root causes (UNAMID, 2014), Indonesian women police as IPO have made significant progress in particular indicators relating to the mandates such as peace, health and education (United Nations, 2015). This significant progress can be seen in Figure 2.

\begin{tabular}{|c|c|c|}
\hline Mandates & Problems & Activities \\
\hline $\begin{array}{l}\text { To protect } \\
\text { civilians; without } \\
\text { prejudice to the } \\
\text { responsibility of } \\
\text { the Government } \\
\text { of Sudan }\end{array}$ & $\begin{array}{l}\text { Rape; Violations of } \\
\text { the Rights to Life; } \\
\text { Violations of the } \\
\text { Rights to Physical } \\
\text { Integrity }\end{array}$ & $\begin{array}{l}\text { Doing weekly patrol plan; } \\
\text { Monitoring the development of } \\
\text { crime in that area including the } \\
\text { cases of sexual gender-based } \\
\text { violence; Analyzing information } \\
\text { about the development of the } \\
\text { crime; Warning local people }\end{array}$ \\
\hline $\begin{array}{l}\text { To facilitate } \\
\text { the delivery of } \\
\text { humanitarian } \\
\text { assistance and } \\
\text { ensure the safety } \\
\text { of humanitarian } \\
\text { personnel }\end{array}$ & $\begin{array}{l}\text { Lack of education } \\
\text { about self-security, } \\
\text { personal health and } \\
\text { the environment, } \\
\text { ways of breastfeeding, } \\
\text { and children's } \\
\text { education; } \\
\text { Access to clean water } \\
\text { in Darfur is very } \\
\text { difficult and force } \\
\text { people to experience } \\
\text { a long-term drought }\end{array}$ & $\begin{array}{l}\text { Providing skill-building } \\
\text { activities, counseling/educating } \\
\text { communities; } \\
\text { Escorts for } 11 \text { logistics convoys } \\
\text { of the World Food Program } \\
\text { (WFP), which consists of } 87 \\
\text { trucks carrying } 1,947 \text { tons of } \\
\text { food and } 46 \text { tons of non-food } \\
\text { items; Provide daily escort to } \\
\text { humanitarian water, hygiene } \\
\text { and sanitation partners, and } \\
\text { transporting water from Kube to } \\
\text { the Sortony gathering site }\end{array}$ \\
\hline $\begin{array}{l}\text { Mediate } \\
\text { between the } \\
\text { Government of } \\
\text { Sudan and non- } \\
\text { signatory armed } \\
\text { movements based } \\
\text { on the Doha } \\
\text { Document for } \\
\text { Peace in Darfur }\end{array}$ & $\begin{array}{l}\text { A prolonged and } \\
\text { violent war between } \\
\text { Janjaweed and } \\
\text { Armed Rebel Groups; } \\
\text { Conflict between two } \\
\text { communities such } \\
\text { as the Berti and the } \\
\text { Ma'aliva }\end{array}$ & $\begin{array}{l}\text { Conducted a meditation between } \\
\text { the Government of Sudan and } \\
\text { Armed Rebel Group to sign a } \\
\text { protocol agreement that was } \\
\text { finalized at the All Darfur } \\
\text { Stakeholders Conference in May } \\
\text { 2011, in Doha, Qatar; Conducted } \\
\text { a meditation between the Berti } \\
\text { and the Ma'aliva in April } 2017\end{array}$ \\
\hline
\end{tabular}




\begin{tabular}{|l|l|l|}
\hline \multicolumn{1}{|c|}{ Mandates } & \multicolumn{1}{c|}{ Problems } & \multicolumn{1}{c|}{ Activities } \\
\hline $\begin{array}{l}\text { Support the } \\
\text { mediation of } \\
\text { community } \\
\text { conflict, including } \\
\text { through measures } \\
\text { to address its root } \\
\text { causes }\end{array}$ & $\begin{array}{l}\text { Women and Children } \\
\text { do not have the right } \\
\text { to speak with the } \\
\text { government }\end{array}$ & $\begin{array}{l}\text { Mediate the local women to } \\
\text { the signing of the Revitalized } \\
\text { Agreement with its requirement } \\
\text { of 35 percent women in the } \\
\text { composition of important } \\
\text { transitional and Governmental } \\
\text { structures in Darfur, Sudan. }\end{array}$ \\
\hline
\end{tabular}

Figure 2. The Progress of Indonesian female IPO

(compiled by the authors)

Through this mission, as shown in Figure 2, Indonesian female Individual Police Officers also protected women and children from the humanitarian crisis in Darfur. They were engaged in advocacies and resilience building for women and children. The advocacy was centered on protecting women and children from sexual abuse and other crimes, empowering women to maintain their physical wellbeing and the growth of their babies by educating proper breastfeeding, outreaching the children by teaching them in classrooms, and teaching them the urgency of protecting the environment. Besides, the Indonesian female IPO also facilitated the local people by providing counseling/educating communities (capacity building) at refugee camps for the local police to maintain security and order, community policing, human rights, education, and health. The elementary session to socialize the foundation of human rights, for instance, might give incentives for women in Darfur to continue postconflict reconstruction by liberating their basic rights.

\section{CONCLUSION}

According to United Nations Police, Individual Police Officers have duties such as providing skill-building activities, building trust with refugees, and ensuring refugees' safety from criminal acts around the mission area. Besides, Indonesian policewomen also have the other duties which are to complete UNAMID mandates such as to (1) protect civilians, without prejudice to the responsibility of the Government of Sudan; (2) facilitate the delivery of humanitarian assistance and ensure the safety of humanitarian personnel; (3) 
mediate between the Government of Sudan and non-signatory armed movements based on the Doha Document for Peace in Darfur; and (4) support the mediation of community conflict, including through measures to address its root causes.

To complete these duties and mandates, Indonesia's government sends women police to the UNAMID for the first time for batch 20172018 because Indonesia has begun to realize gender equality. These women police are AKBP Yunik Dwi Astuti, SIK, MSi, Kompol Rusdiani, SIK, MSi, Iptu Wastini, Brigadir Fraya Sadewi, AKBP Dr. Imanta Tarigan, Bripka Aprina Pohan, Bripka Anastasia Helena Rompas, Bripka Ni Nyoman Trisna Oktaviani, and Bripka Lucy Veronika. The deployment of Indonesian female police in UNAMID has shown that the counterinsurgency measurement also signifies the role of police security to accompany the human security concept in peacekeeping and gendering international peace and security can be accelerated.

\section{BIBLIOGRAPHY}

Arsenijevic, D., \& Flessenkamper, T. (2013). What is the Gender of Security? Sarajevo Open Centre.
Astuti, Y. D. (2017). Kiprah 9 Srikandi Polwan Indonesia pada Misi UNAMID Darfur Sudan. Tribata News.

Bayley, D. H., \& Perito, R. M. (2010). The Police in War: Fighting Insurgency, Terrorism and Violent Crime. Lynne Rieener Publishers.

Dharmapuri, S. (2013). Not Just a Numbers Game: Increasing Women's Participation in UN Peacekeeping. https://www. ipinst.org/2013/07/not-justa-numbers-game-increasingwomens-participation-in-unpeacekeeping

Durch, W. J., \& Ker, M. (2013). Police in UN Peacekeeping: Improving Selection, Recruitment, and Deployment. https://www.jstor. org/stable/resrep09594.11

Eikenberry, K. W. (2013). The Limits of Counterinsurgency Doctrine in Afghanistan. Foreign Affairs. https://www. foreignaffairs.com/articles/ afghanistan/2013-08-12/limitscounterinsurgency-doctrineafghanistan

Guehenno, J. M. (2006). Gender Equality in UN Peacekeeping Operations. https://www. peacewomen.org/sites/default/ files/pk_policydirectiveon- 
genderequalityinunpeacekeepingoperations_dpko_2006. pdf

Human Rights Watch. (2015). World Report 2015: Sudan Events of 2014. Human Rights Watch. https://www.hrw.org/worldreport/2015/country-chapters/ sudan

Loh, J. (2010). Success factors for police reform in post-conflict situations. Hertie School of Governance.

Mazurana, D. (2003). Do Women Matter in Peacekeeping? Women in Police, Military, and Civilian Peacekeeping. Canadian Woman Studies, 22(2), 64-71. https://cws. journals.yorku.ca/index.php/ cws/article/view/6488

The Constitution of the Republic of Indonesia of 1945, (1945).

Netabay, N. (2009). The Darfur Peace Process: Understanding the Obstacles to Success. https:// www.beyondintractability.org/ casestudy/netabay-darfur

Odanovic, G. (2010). Participation of Women in UN Peacekeeping Operations. Western Balkans Security Observer, 16, 70-78.

Undang-Undang Republik Indonesia Nomor 2 Tahun 2002 Tentang Kepolisian Negara
Republik Indonesia, (2002). http://hukum.unsrat.ac.id/uu/ uu_2_02.html

Syam, M. N., Taringan, I., \& Veronika, L. (2017). Laporan Akhir Penugasan Misi Pemeliharaan Perdamaian PBB UNAMID di Darfur Sudan IPO Indonesia Kontingen 2016-2017. Timur, F. B. (2016). The Tales of Three Asian Countries: How Indonesian, India and The Philippines Recruited Women for UN Peacekeeping Missions. Global, 18(1), 51-75.

U.S.Department of State. (2017). SUDAN. U.S. Department of State Diplomacy in Action. https://www.state.gov/j/drl/rls/ hrrpt/2016/af/265306.htm

UNAMID. (2014). UNAMID Mandate. United NationsAfrican Union Hybrid Operation in Darfur. https:// unamid.unmissions.org/ unamid-mandate

UNAMID. (2017). About UNAMID. United Nations-African Union Hybrid Operations in Darfur. https://unamid.unmissions. org/about-unamid-0

United Nations. (2007). Fact Sheet. The United Nations and Darfur. http://www.un.org/News/dh/ infocus/sudan/fact_sheet.pdf 
United Nations. (2015). Leaders' Summit on Peacekeeping. United Nations Peacekeeping. https:// peacekeeping.un.org/en/ leaders-summit-peaceekeeping United Nations. (2017). Individual Police Officers. https://police. un.org/en/individual-policeofficers

United Nations Police. (2016). Recruiting more policewomen. United Nations Police. https:// police.un.org/en/recruitingmore-police-women

Wibisono, T. H. (2018). Laporan

Akhir Pelaksanaan Tugas pada Misi Perdamaian PBB UNAMID di Sudan tanggal 29 Januari 2017 s/d 28 Januari 2018. 